\title{
GUANIDINE RETENTION AND CALCIUM RESERVE AS ANTAGONISTIC FACTORS IN CARBON TETRACHLO- RIDE AND CHLOROFORM POISONING
}

By A. S. MINOT AND J. T. CUTLER

(From the Department of Pharmacology, Vanderbilt University School of Medicine, Nashville)

(Received for publication August 27, 1928)

\section{INTRODUCTION}

Carbon tetrachloride, even in very large doses, has been shown by Lamson et al. (1) to produce no acute intoxication in dogs on a well balanced mixed diet. A preliminary note from this labortory (2) reported, however, that similar or even very small doses of the drug caused a severe and usually fatal poisoning in dogs on a diet of lean meat without bones. One radical difference in the two diets was the decreased calcium content of the meat diet. It was found that by the addition of simple calcium salts to this ration practically the same tolerance to carbon tetrachloride could be obtained as was reported by Lamson. Furthermore, cases of intoxication could usually be successfully treated by calcium therapy. The present paper enlarges upon the preliminary report and contains a report of further studies carried out in an attempt to explain the rôle played by calcium in furnishing this protection.

The signs of intoxication produced by carbon tetrachloride in animals on meat diets low in calcium

The intoxication produced by the administration of 3 or $4 \mathrm{cc}$. of carbon tetrachloride per kilo body weight to dogs made susceptible by a preliminary diet of lean meat without extra calcium, usually runs the following course: For 12 to 20 hours after giving the dose of carbon tetrachloride no symptoms are noted other than a slight malaise and some salivation and nausea. Sometimes the appetite is poor but frequently meat is eaten eagerly a few hours after the dose. Diarrhea with the passing of considerable amounts of carbon tetrachloride is 
often seen. After about 20 hours, or sometimes earlier if a meal of meat is eaten, the dogs become definitely ill, refuse to move about unless urged, and usually have fibrillary tremors which can be felt in most of the skeletal muscles. Visible twitching of the paws and lips soon follows and becomes more marked during the next 12 hours. Violent general convulsions are sometimes seen, especially when aroused by some outside stimulus such as handling. At this stage a foul bloody diarrhea is frequently seen with vomiting of black material containing changed or even fresh blood. The dogs then grow gradually weaker and the convulsive twitching becomes more feeble or disappears. There may be coma, but more often there is a profound weakness with consciousness retained. Death most often occurs between 48 and 60 hours after the dose and is usually from weakness or exhaustion but occasionally comes suddenly in the midst of a convulsive seizure. Convulsive symptoms are occasionally entirely absent and death follows a period of depression and coma.

As has been previously noted by Lamson (1), Meyer and Pessoa (3), and Davis (4), the most obvious damage done by carbon tetrachloride is to the liver. At autopsy this organ appears yellowish and the lobules are definitely outlined with red central areas surrounded by yellow tissue. On section this same appearance is seen throughout the tissue. The liver feels very greasy and is so soft and friable that it can be readily mashed in the fingers. Sometimes the lobes contain cracks from which loss of blood into the peritoneal cavity may have reached the proportion of severe hemorrhage. This finding is most common in the type of death mentioned above which ensues rapidly in the midst of a convulsive seizure. In such cases as much as a liter of blood may be found in the abdominal cavity and this hemorrhage is apparently the immediate cause of death. More commonly, however, the liver though congested and friable is not ruptured. The gastro-intestinal tract usually contains old blood and sometimes fresh blood is seen oozing from numerous hemorrhagic areas in the pyloric end of the stomach and upper third of the small intestine. Congestion in these portions of the tract is very marked and is not due to the local irritation of carbon tetrachloride since the same doses of the drug cause no such condition in adequately protected animals. The kidneys show no very striking abnormality though some congestion is often noted 
Since the micropathology will be dealt with in detail in a later paper it is sufficient here to state that there is a severe central necrosis of the liver with very marked fatty infiltration, so that in many cases practically no normal liver cells remain.

\section{Calcium as a preventive and cure of this intoxication}

The occurrence of cases of acute intoxication only after there had been a radical reduction in dietary calcium, as well as the similarity of the convulsive symptoms to tetany associated with calcium lack, suggested the treatment of poisoned animals by calcium administration. The relief afforded very sick dogs by the intravenous injection of calcium chloride was very gratifying - a dog in convulsions or coma responding within a few minutes to half an hour, and becoming temporarily fairly normal. Further experiments showed that most cases of intoxication could be permanently cured by a suitable course of calcium therapy. Just what constitutes a suitable course depends largely on the individual case. If started early enough the repeated administration of calcium chloride or lactate by mouth after the dose of carbon tetrachloride has been given will often serve to prevent serious symptoms if vomiting is not persistent. Ammonium chloride, or hydrochloric acid, which furnish calcium ions indirectly by liberating them from the skeletal store are also effective. When vomiting is persistent, or convulsive symptoms appear in spite of oral medication, or the case is far advanced before medication is started, prompt relief can usually be afforded by intravenous administration of calcium chloride. The parathyroid extract prepared by Collip (5) has also been successfully used and its action will be discussed in more detail in a later paper. This has the advantages of ease of administration and of causing a prolonged increase in blood calcium, but the disadvantage of a considerable latent period before the effect is obtained. In using this extract or intravenous calcium medication the danger of hypercalcemia from overdosage must always be kept in mind. Successful results depend largely upon an early start. When the intoxication has progressed to the point where loss of blood into the gastro-intestinal tract is severe or the tense brittle liver ruptures nothing can be done. If, however, these symptoms are prevented 
by the early administration of calcium the majority of dogs can be cured by persistent medication during the 3 or 4 days of severe intoxication.

Typical protocols of 2 of about 25 dogs cured by calcium therapy serve to illustrate the usual course of treatment. The first dog reported required medication somewhat longer than is usually necessary after receiving $4 \mathrm{cc}$. of carbon tetrachloride per kilogram. The case is otherwise perfectly typical and is chosen for presentation here because it illustrates the use of several forms of calcium therapy. The second dog required less persistent treatment but in other respects is very similar to the first one. Later work has shown the inadvisability of allowing poisoned or convalescent dogs to eat meat but this point was not appreciated at the time of these particular experiments.

Protocol, Case T. D. 11. Brindle and white male, weight $7.9 \mathrm{kgm}$. On low calcium meat diet 2 to 3 weeks before experiment.

January 22, 1927:

3:00 p.m. Received $4 \mathrm{cc}$. $\mathrm{CCl}_{4}$ per kilogram by stomach tube-total dose $31.6 \mathrm{cc}$.

January 23, 1927:

9:00 a.m. Has slight twitching of paws and lips.

10:00 a.m. Given $100 \mathrm{cc}$. of 5 per cent calcium lactate by stomach tube.

2:00 p.m. Appears very sick, breathing irregularly due to spasmodic contractions of the diaphragm.

6:00 p.m. Has violent tetanic convulsions. Given $500 \mathrm{mgm}$. of $\mathrm{CaCl}_{2}$ intravenously as 5 per cent solution.

6:30 p.m. Seems much better-convulsions have ceased entirely.

8:00 p.m. Dog is perfectly quiet, conscious but weak.

9:00 p.m. Slight muscular twitching reappears. Given $350 \mathrm{mgm}$. of $\mathrm{CaCl}_{2}$ intravenously as 1 per cent solution. Dog vomited undigested meat eaten two days before.

10:00 p.m. Seems much better, walks around the room, has no tremor. January 24, 1927:

10:00 a.m. Seems rather weak but has no convulsive symptoms. Given $100 \mathrm{cc}$. of milk and $100 \mathrm{cc} .5$ per'cent calcium lactate by stomach tube.

2:00 p.m. Condition unchanged. Given $150 \mathrm{cc}$. of milk, $100 \mathrm{cc} .5$ per cent calcium lactate by stomach tube.

8:00 p.m. Condition unchanged. Given $150 \mathrm{cc}$. of milk, $100 \mathrm{cc} .5$ per cent calcium lactate by stomach tube.

January 25,1927 :

9:00 a.m. Has fine tremor in paws. Given $100 \mathrm{cc}$. of milk, $50 \mathrm{cc} .5$ per cent calcium lactate and $1 \mathrm{egg}$ by stomach tube. 
12:00 noon. Has definite tetanic convulsions. Given $500 \mathrm{mgm} . \mathrm{CaCl}$ intravenously.

2:30 p.m. Twitching has entirely stopped. Dog given 100 cc. 5 per cent calcium lactate and $50 \mathrm{cc}$. of milk by stomach tube.

6:00 p.m. Seems well but rather weak. Given $100 \mathrm{cc}$. of milk, $1 \mathrm{egg}$ and 100 cc. 5 per cent calcium lactate by stomach tube.

January 26, 1927:

9:00 a.m. Condition unchanged. Given $100 \mathrm{cc}$. of milk, $1 \mathrm{egg}$ and $100 \mathrm{cc}$. 5 per cent calcium lactate by stomach tube. Has diarrhea-feces of cream-like consistency and appearance-absorption from the gastrointestinal tract is apparently poor.

4:00 p.m. Has typical tetanic convulsions. Given $450 \mathrm{mgm}$. of $\mathrm{CaCl}_{2}$ intravenously as 5 per cent solution. All muscle twitching stopped within 15 minutes.

6:00 p.m. Quiet but weak. Given $100 \mathrm{cc}$. of milk, $100 \mathrm{cc} .5$ per cent calcium lactate by stomach tube. Has persistent diarrhea.

10:50 p.m. Convulsive twitching reappears. Given $500 \mathrm{mgm} . \mathrm{CaCl}_{2}$ intravenously as 5 per cent solution. Good response.

January 27, 1927:

9:00 a.m. Seems better but has slight tremor. Given $100 \mathrm{cc}$. of molar $\mathrm{NH}_{4} \mathrm{Cl}$ by stomach tube-vomited.

10:45 a.m. Has tetanic convulsions. Given $500 \mathrm{mgm} . \mathrm{CaCl}_{2}$ intravenously. Complete relief in about 15 minutes.

2:00 p.m. Given $50 \mathrm{cc}$. molar $\mathrm{NH}_{4} \mathrm{Cl}, 100 \mathrm{cc}$. of milk and $1 \mathrm{egg}$ by stomach tube.

4:30 p.m. Given 30 cc. molar $\mathrm{NH}_{4} \mathrm{Cl}$ by stomach tube.

January 28, 1927:

8:00 a.m. Seems much better. Given $60 \mathrm{cc}$. molar $\mathrm{NH}_{4} \mathrm{Cl}$ by tube. Eats a little meat.

11:30 a.m. Having violent convulsions. Given $500 \mathrm{mgm}$. $\mathrm{CaCl}_{2}$ intravenously. Very good response.

4:00 p.m. Seems very much better. Eats meat eagerly. Given 5 grams of a mixture of calcium lactate and carbonate with the meat.

8:00 p.m. Dog seems rather sick and has considerable tremor but gradually recovers during the night without further medication.

January 29, 1927:

9:00 a.m. Dog seems much more active. Eats eagerly. Given 5 grams of calcium salt mixture with meat and bread.

4:00 p.m. Eats another meal eagerly. Seems practically well.

January 30, 1927 to February 2, 1927: Dog active and has good appetite. Seems completely recovered. Discharged. 
Protocol, Case T. D. 32 . Weight $7.8 \mathrm{kgm}$. On low calcium meat diet for 3 weeks before experiment.

February 28, 1927:

3:00 p.m. Given $4 \mathrm{cc}$. $\mathrm{CCl}_{4}$ per kilogram by stomach tube-total dose $31.2 \mathrm{cc}$.

8:00 p.m. Resting quietly.

March 1, 1927:

9:00 a.m. Good condition.

10:00 a.m. Given $50 \mathrm{cc}$. molar $\mathrm{NH}_{4} \mathrm{Cl}$ by stomach tube.

2:00 p.m. Given 50 cc. molar $\mathrm{NH}_{4} \mathrm{Cl}$ by stomach tube.

3:30 p.m. Given $100 \mathrm{cc} .5$ per cent calcium lactate, $100 \mathrm{cc}$. of milk and 1 egg by stomach tube.

9:00 p.m. Good condition. Given 100 cc. 5 per cent calcium lactate by stomach tube.

March 2, 1927:

9:00 a.m. Fair condition. Given $30 \mathrm{cc}$. molar $\mathrm{NH}_{4} \mathrm{Cl}, 175 \mathrm{cc}$. of milk and 1 egg by tube-vomited.

12:15 p.m. Dog lying on side with violent muscle twitching -is only semiconscious. Given $450 \mathrm{mgm}$. $\mathrm{CaCl}_{2}$ intravenously as 5 per cent solution. The twitching stops within 20 minutes and the dog stands up apparently normal.

8:00 p.m. Still in good condition. Given 50 cc. 5 per cent calcium lactate and $100 \mathrm{cc}$. of milk by stomach tube.

10:00 p.m. The eight o'clock medication was repeated.

March 3, 1927. Dog in good condition. Has good appetite and eats a meal of meat, bread, a little milk and 5 grams of a mixture of calcium lactate and carbonate.

March 4, 1927. Dog in good condition. Eats well, apparently normal.

March 5, 1927. Discharged.

Of more practical interest than the treatment of poisoned animals is the highly protective action of a preliminary course of a diet high in calcium. This is obtained by the daily addition of about 5 grams of a mixture of calcium carbonate and lactate to the meat diet for 1 to 3 weeks before giving carbon tetrachloride. From a total of 105 dogs on a low calcium meat diet used for various experiments, 84 died with typical symptoms following $4 \mathrm{cc}$. of carbon tetrachloride per kilogram. Of the 21 surviving, 6 were desperately ill for several days, 6 refused to eat meat after the administration of carbon tetrachloride, and 9 showed no serious symptoms. In contrast to this 75 from a total of 95 on a diet of meat and calcium salts showed no serious symptoms. 
Eight died a few hours after eating meat and 12 died with symptoms similar to those seen in dogs on a low calcium meat diet.

Even more striking are the results from repeated dosing with carbon tetrachloride. Lamson (1) had previously reported that large amounts of carbon tetrachloride, as much as 2 liters in some cases, could be given in divided doses over considerable periods of time without symptoms. The first 40 animals on plain meat diet to which we tried to give repeated doses died before more than 2 or 3 small doses had been given. After calcium was added 20 dogs were carried through several months on weekly doses of $2 \mathrm{cc}$. of carbon tetrachloride per kilo without a single loss from acute intoxication. Some have been sacrificed and show typical cirrhosis with ascites. Others are still in apparent health after more than a year of repeated dosing.

\section{Comparison of liver pathology and blood chemistry in high and low calcium} groups after carbon tetrachloride administration

These clean-cut results obtained in the two groups made it seem likely that some consistent dissimilarity would be found either in the degree of damage done by carbon tetrachloride to the liver or in some condition secondary to this injury. Such a difference would give some indication of the rôle played by calcium in affording the protection already described.

Pathology. Although we hope that detailed microscopic studies by means of various stains will bring out certain qualitative differences in the pathological pictures produced in the two groups a cursory study serves to show that on the whole comparable amounts of liver destruction have occurred in animals on high and low calcium meat diets. Even in dogs with sufficient calcium to prevent serious symptoms there is a severe central necrosis, though there seems to be less fat present, and the liver tissue feels more firm. The additional fact that typical liver cirrhosis is gradually produced by the repeated administration of carbon tetrachloride to animals adequately protected by calcium against acute symptoms would argue against any real protection of the liver.

Liver function tests. Studies with the usual liver function tests, such as Rosenthal's phenoltetrachlorphthalein test (6), levulose tolerance tests, fibrin determinations, etc., further emphasize the lack 
TABLE 1

Icteric indices determined* before and at intervals after administration of $4 \mathrm{cc}$. of $\mathrm{CCl}_{4}$ per kilogram to dogs on high and low calcium meat diets

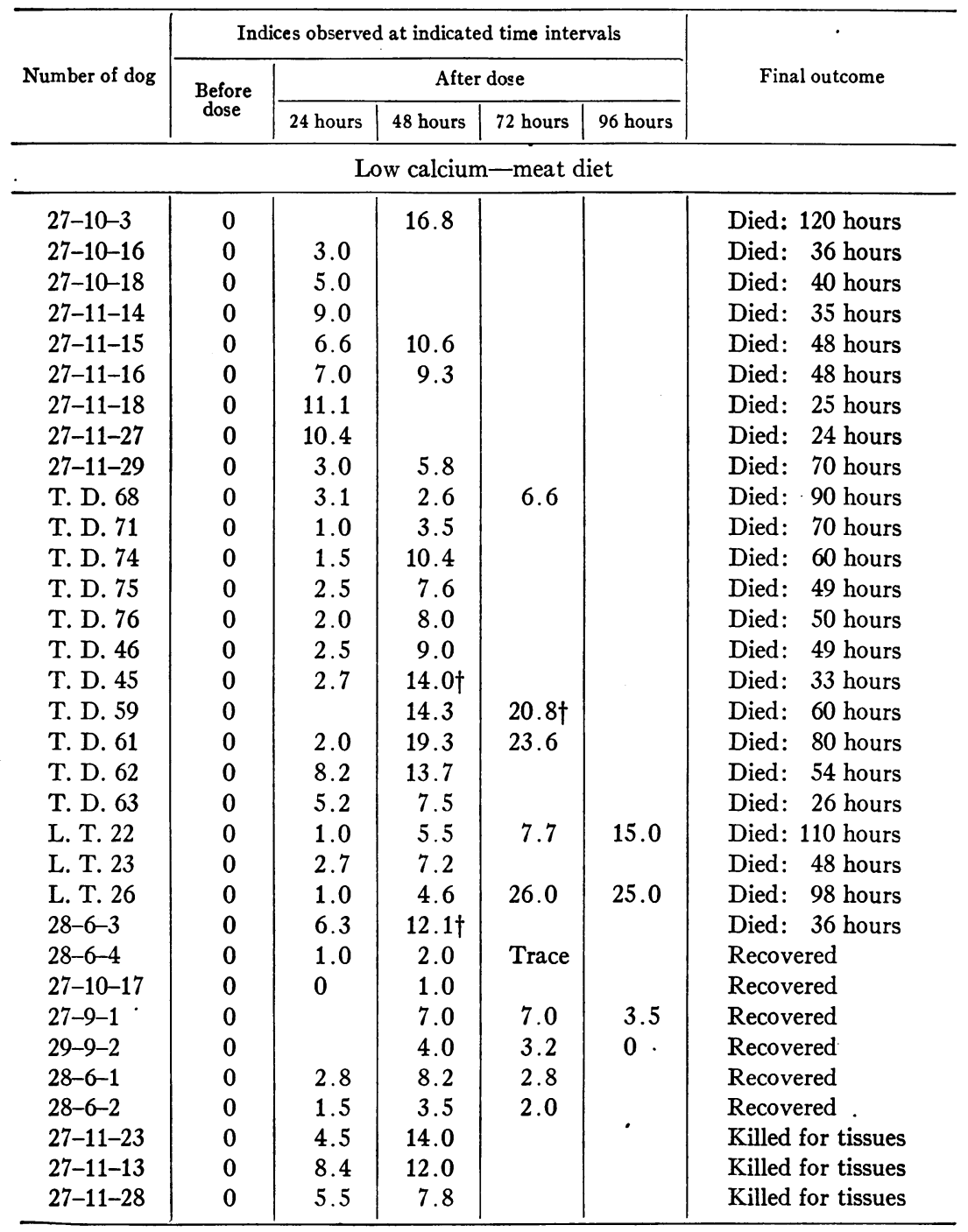


TABLE 1-Continued

\begin{tabular}{|c|c|c|c|c|c|c|}
\hline \multirow{3}{*}{ Number of dog } & \multicolumn{5}{|c|}{ Indices observed at indicated time intervals } & \multirow{3}{*}{ Final outcome } \\
\hline & \multirow{2}{*}{$\begin{array}{l}\text { Before } \\
\text { dose }\end{array}$} & \multicolumn{4}{|c|}{ After dose } & \\
\hline & & 24 hours & 48 hours & 72 hours & 96 hours & \\
\hline \multicolumn{7}{|c|}{ High calcium-meat diet } \\
\hline $27-10-10$ & 0 & 0 & 0.5 & 0 & 0 & Recovered \\
\hline $27-10-23$ & 0 & 0 & 0.5 & & 0 & Recovered \\
\hline $27-10-24$ & $\mathbf{0}$ & 2.7 & 1.0 & & 0 & Recovered \\
\hline $27-10-25$ & 0 & 1.0 & 0.5 & & 0 & Recovered \\
\hline $27-10-26$ & 0 & 1.0 & 0.5 & & 0 & Recovered \\
\hline $27-12-9$ & 0 & 0.5 & 0.5 & & 0 & Recovered \\
\hline $27-12-10$ & 0 & 1.0 & 2.0 & & 0 & Recovered \\
\hline $27-12-11$ & 0 & 0 & 0.5 & & 0 & Recovered \\
\hline $27-12-12$ & 0 & 0.5 & 2.5 & & 0 & Recovered \\
\hline $27-12-13$ & 0 & 0 & 0.5 & & 0 & Recovered \\
\hline $27-12-15$ & 0 & 0 & 0.5 & & 0 & Recovered \\
\hline $27-12-2$ & 0 & 0 & 0 & & 0 & Recovered \\
\hline $27-12-3$ & 0 & 0 & 0.5 & & 0 & Recovered \\
\hline $27-12-4$ & 0 & 2.0 & 2.0 & & & Recovered \\
\hline $27-12-6$ & 0 & 0 & 0 & & 0 & Recovered \\
\hline $26-12-7$ & 0 & 0 & 0 & & 0 & Recovered \\
\hline T. D. 49 & 0 & 1.0 & 3.2 & 0.5 & 0 & Recovered \\
\hline T. D. 65 & 0 & & 3.5 & 0 & 0 & Recovered \\
\hline T. D. 66 & 0 & 3.5 & 3.5 & 2.7 & 0 & Recovered \\
\hline T. D. 67 & 0 & 0 & 1.6 & 0 & & Recovered \\
\hline T. D. 70 & 0 & 0 & 0 & 0 & 0 & Recovered \\
\hline T. D. 72 & 0 & 1.0 & 4.0 & - 2.0 & 0 & Recovered \\
\hline T. D. 73 & 0 & 0 & 2.0 & 3.0 & 0 & Recovered \\
\hline $28-6-7$ & 0 & 1.0 & 1.0 & 1.5 & 0 & Recovered \\
\hline $28-6-8$ & 0 & 9.8 & 10.0 & 8.6 & 3.0 & Recovered \\
\hline $28-6-9$ & 0 & 3.1 & 2.5 & Trace & 0 & Recovered \\
\hline $28-6-6$ & 0 & 6.2 & 3.5 & & & Died: 60 hours \\
\hline $27-11-3$ & 0 & 0.5 & 0.5 & 4.1 & & Died: 48 hours \\
\hline $27-11-8$ & 0 & & 5.7 & 8.7 & & Died: 48 hours \\
\hline $27-11-31$ & 0 & 2.5 & & & & Died with snuffles \\
\hline
\end{tabular}

* The method used for the determination of the icteric indices was a modification of Bernheim's (8) technique. The proteins of blood serum were removed by adding 2 volumes of absolute alcohol and centrifuging. The clear supernatant alcoholic solution containing the bilirubin was compared in a colorimeter with a standard potassium dichromate solution prepared according to Bernheim's directions. A solution of 1:10,000 potassium dichromate solution was taken to represent an icteric index of 1 . With the standard dichromate solution set at $20 \mathrm{~mm}$. in the colorimeter the calculation is as follows:

$\begin{array}{llll}\frac{20}{\text { Reading of }} \\ \text { unknown }\end{array} \times \quad \begin{aligned} & \text { Index of } \\ & \text { Standard }\end{aligned} \times \quad \begin{aligned} & \text { Dilution of } \\ & \text { bilirubin } \\ & \text { solution }\end{aligned}=\begin{aligned} & \text { Index of } \\ & \text { blood } \\ & \text { serum }\end{aligned}$

$\dagger$ This sample taken at time of death. 
of any clean-cut difference in the degree of derangement of these functions in the two groups. Some cases show a retention of phenoltetrachlorphthalein but these are as likely to be found in one group as the other. Furthermore, although there is a very definite decreased tolerance for levulose in the majority of cases which have received carbon tetrachloride there is a disappointing lack of parallelism between the severity of symptoms and the degree of hyperglycemia produced by the ingestion of a given amount of levulose.

Blood chemistry. a. Bilirubinemia. The determination of bilirubin in the blood serum either by van den Bergh's method (7) or more simply by the determination of the icteric index by a modification of Bernheim's technique (8) furnished data more nearly parallel with the severity of symptoms. In table 1 are presented icteric indices determined at intervals after carbon tetrachloride administration to dogs in the high and low calcium groups described above. In general the bilirubinemia tends to be much more severe in the animals on low calcium diet than in those protected by high calcium. Exceptions to this rule are usually seen in the occasional unexplained atypical cases in each group. The retention of bile pigments begins to be noticeable 12 to 20 hours after the dose of carbon tetrachloride, and usually as the bilirubinemia becomes severe the more acute symptoms appear. The reason for the lower concentration of bilirubin in the blood of animals on high calcium diets is still unexplained. An observation which suggests a possible theory is the much greater tendency for the tissues of high calcium animals to appear jaundiced. It may be possible that tissues well laden with calcium tend to hold bilirubin, perhaps in combination with calcium, preventing its accumulation in the blood stream.

b. Blood calcium determinations. The total blood calcium levels of normal dogs determined by Clark and Collip's modification of Tisdall's method (9) showed no consistent differences in the two groups and ranged between 10.5 and $12.0 \mathrm{mgm}$. per $100 \mathrm{cc}$. of serum. During severe intoxication there is no significant change in the total calcium concentration. The figures are within normal limits with a tendency in many cases to average slightly higher than the preliminary level before receiving carbon tetrachloride. No data have yet been obtained regarding possible changes in the ionized fraction of the total 
calcium. The prompt relief of symptoms after supplying extra calcium seems to indicate either a lack or an excessive demand for calcium ions. The idea that such a lack may be associated with the bilirubinemia just described is supported by King and Stewart (10) and King, Bigelow and Pearce (11). Later work by Bowler and Walters (12) shows that the lethal intravenous dose of calcium chloride is much higher for jaundiced than for normal dogs, because of the removal of calcium ions by combination with biliary constituents. Buchbinder and Kern (13) likewise have recently reported faulty calcification of bones in chronic jaundice. Although the bilirubinemia probably represents one factor in the need for calcium in carbon tetrachloride intoxication, further experimental work has made it more and more evident that other factors are also involved.

c. Blood sugar studies. During the levulose tolerance experiments mentioned above it was repeatedly observed that the blood sugar levels in fasting dogs preliminary to the administration of levulose tended to be low during carbon tetrachloride intoxication. Sugar concentrations as low as 40 to $50 \mathrm{mgm}$. per $100 \mathrm{cc}$. were frequently found in very sick dogs. The same tendency was seen in animals on the meat diet, both with and without added calcium, but the fall rarely reached the level of real pathological hypoglycemia except in the sick dogs on low calcium diet. With this observation as a basis, series of blood sugar determinations with repeated tests for sugar in urine were run on 25 dogs at intervals of a few hours throughout the period of intoxication or until death. Benedict's later blood sugar method (14) was used in these studies. Parallel determinations were run in many instances by the Folin-Wu (15) procedure and these showed the same changes in blood sugar level though all the figures tended to run a few milligrams higher. The results obtained were very consistent. No abnormal excretion of sugar in the urine was found in these or later cases. Even animals protected by calcium show a tendency to somewhat lowered blood sugar concentrations after eating meat while in the severe intoxication in animals on low calcium diet such extremely low blood sugar levels were found that it seems that hypoglycemia must be an important factor in, if not the chief cause of death. The blood sugar figures reported in table 3 in connection with other observations are entirely typical of these 
results so no special table of blood sugar figures is inserted at this point.

Briefly summarized, the intoxication produced by carbon tetrachloride in susceptible animals is characterized by gastro-intestinal irritation, nervous disturbances and convulsions, followed by weakness, depression, and death. There is a retention of bile pigments in the blood and a more or less severe hypoglycemia. These symptoms are aggravated by eating meat and may be prevented or cured by the administration of calcium salts.

Points of similarity between carbon tetrachloride intoxication and experimental guanidine poisoning

The foregoing pathological picture calls to mind similar ones described in the literature as typical of guanidine poisoning. As early as 1876 Gergens and Baumann (16) described the effect of intravenous injections of guanidine sulphate in frogs and mammals. Dogs and rabbits showed weakness, fibrillary twitching of muscles, convulsions and death following injection. Putzeys and Swaen (17), Fühner (18) (19) Camis (20) and others contributed numerous studies on the action of guanidine compounds on various parts of the nervous system and on the skeletal musculature of frogs-Fühner bringing out the antagonism which exists between the actions of calcium salts and guanidine on these structures. More extensive mammalian experiments were reported by Watanabe (21) (22) (23) (24) (25) in a series of papers in which he again described the nervous symptoms, studied nitrogen metabolism, and reported that a severe hypoglycemia was induced. This he ascribed to a condition of acidosis which he believed was indicated by increased ammonia excretion in the urine. György and Vollmer (26) however discredited the acidosis theory and found rather a condition of alkalosis and reported that the symptoms of guanidine intoxication can be relieved by the administration of hydrochloric acid either intravenously or by mouth. Paton and Findlay (27) studied the intoxication produced by guanidine or methyl guanidine and described symptoms very similar to the tetany seen after parathyroidectomy and believed that the two conditions are identical. Perhaps the most complete pharmacological and toxicological study of guanidine compounds which we have is a paper 
by Frank, Stern, and Nothmann (28). A variety of guanidine compounds were used with adequate numbers of animals of different species, the lethal doses carefully determined, and the symptoms noted. In dogs a lethal dose of $250 \mathrm{mgm}$. per kilogram of guanidine hydrochloride produced symptoms of tremor, restlessness, hoarse barking, salivation, vomiting, diarrhea, apathy, weakness and death. Cats showed a more prolonged and violent toxic picture if the dose was graded so that death was not too rapid. Doses of $100 \mathrm{mgm}$. per kilogram produced hyperexcitability, tremors, violent extensor spasms and diarrhea over a period of 3 or 4 days finally leading to death or a gradual recovery. From this study and our own later work, cats seem to be considerably more susceptible than dogs to guanidine poisoning - a point of considerable interest in view of the greater susceptibility of cats to carbon tetrachloride poisoning (29). There is some disagreement regarding the blood calcium level in guanidine poisoning. Watanabe (25) and György and Vollmer (26) found lowered calcium content while Nelken (30) found the concentration of total blood calcium normal or even high. Bayer (31) reported that while the total calcium level may be approximately normal there is a reduction in the ionized fraction.

In our own experience a lethal dose of 200 to $250 \mathrm{mgm}$. of guanidine hydrochloride per kilogram body weight administered subcutaneously produced an intoxication very similar to carbon tetrachloride poisoning. Coughing due to laryngeal spasm is an early symptom followed by fibrillary twitching of muscles and more or less severe tetanic convulsions which are much aggravated by handling the animal. A period of several hours of extreme depression and weakness usually precedes death. Salivation and vomiting are common and the vomitus is often bloody. At autopsy the pyloric end of the stomach and upper third of the small intestine show extreme congestion with many small hemorrhagic areas. Blood sugar determinations show that after a preliminary rise, probably due in part at least to nervous excitement early in the intoxication, there is a fall in blood sugar. This begins about 4 or 5 hours after the guanidine is administered and in many cases extreme hypoglycemia is produced before death. The severity of the hypoglycemia caused by a given dose of guanidine seems to be considerably influenced by previous diet and 
much lower blood sugar levels are reached after a lean meat diet than after a liberal mixed diet containing an abundance of calcium and carbohydrate. The blood calcium concentrations are found to be normal or slightly increased.

There are so many points in common in guanidine and carbon tetrachloride intoxications that attempts were made to determine whether guanidine plays any part in the toxic state seen after carbon tetrachloride administration.

\section{Method for determination of guanidine in blood}

The determination of the very small amounts of guanidine present in amounts of blood which can be taken at repeated intervals from experimental animals is a difficult problem. Indeed it was entirely impractical to attempt this until the appearance of the colorimetric methods which were developed from the color reaction described by Tiegs (32). The original observation was that a reddish color was developed with guanidine compounds by a solution of sodium nitroprusside which had been allowed to oxidize for some time by exposure to air and sunlight. This reagent also gave the color with numerous related compounds such as creatine and creatinine. Various changes in this reagent to increase its delicacy and specificity were contributed by Marston (33) Pfiffner and Meyer (34) and a method adaptable to the determination of guanidine in relatively small amounts of blood was finally described in 1927 by Major and Weber (35). The reagent described by them is made as follows:

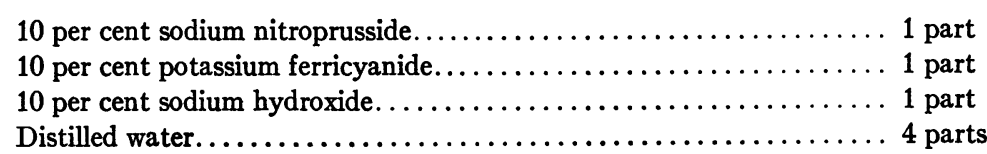

The solutions are kept separately and a small amount of reagent mixed for use each day. This differs from the reagent of Pfiffner and Meyer essentially in the substitution of potassium ferricyanide for ferrocyanide and the omission of hydrogen peroxade to bring about the oxidation. In our experience we have found that a much less highly colored reagent and one which is equally sensitive is obtained by substituting one volume of 3 per cent hydrogen peroxide for one of the four volumes of water. This gives a pale greenish yellow reagent, 
$1 \mathrm{cc}$. of which gives an appreciable reddish orange color with as little as $0.02 \mathrm{mgm}$. of guanidine in a volume of $6 \mathrm{cc}$.

The authors do not claim, nor do we find, a strict specificity of this reagent for guanidine. Of the substances normally present in the blood, creatine (methyl guanidine acetic acid) gives the most interference. When the guanidine reagent is added directly to aqueous solutions of creatine and guanidine approximately the same color is produced by $0.5 \mathrm{mgm}$. of creatine as by $0.05 \mathrm{mgm}$. of guanidine. If, however, the same amount of creatine is added to blood and carried through the entire procedure to be described later, a portion of it is apparently destroyed because the color produced becomes much less. Creatinine gives only about one-hundredth as much color as guanidine while the interference from urea and other nitrogenous constituents is slight. No attempt has been made to increase the specificity of the reagent but rather to show that in cases where there is a five or ten-fold increase in the color produced by the filtrate obtained from a given amount of blood, there has been no significant simultaneous increase in any of the interfering substances. When sufficient amounts of blood are available creatine, urea, etc. can be determined and corrected for in the final result. It is also possible to convert the creatine to creatinine without destroying appreciable amounts of the guanidine present and so minimize the color interference. When all these precautions are taken the preliminary guanidine figure is considerably lowered-from about 0.35 to 0.40 to about 0.18 to 0.25 mgm. per $100 \mathrm{cc}$. of blood. ${ }^{1}$ In severely poisoned animals, however, when there has been a rise to uncorrected levels of 1.00 to $2.50 \mathrm{mgm}$. per $100 \mathrm{cc}$. of blood the correction to be applied is not found to have increased correspondingly but to represent still about 0.2 to $0.3 \mathrm{mgm}$. per $100 \mathrm{cc}$. which does not appreciably affect the significance of the rise. Indeed with the lower preliminary level the percentage variation

\footnotetext{
${ }^{1}$ The necessary correction of guanidine figures due to the interference of creatine and other nitrogenous constituents of the blood is discussed in a later paper by Major and Weber (36). A modification of their method for guanidine determination is also described. This paper did not come to our attention until our experimental work had been finished. It is interesting to note however, that the corrections which they find it necessary to apply are about the same as we have reported above.
} 
from normal during intoxication is increased rather than decreased by the correction. Since we wished to keep the volume of blood required for each determination as small as possible in order to make repeated studies on the same animal at short intervals-these corrections were not applied except in a few preliminary observations. The figures given in table 3 are the uncorrected values obtained. We therefore make no claim for their absolute accuracy within 0.2 to $0.3 \mathrm{mgm}$. per $100 \mathrm{cc}$. of blood. We know the values are as a rule slightly high. We do however make the point that the rise in color producing substances occurs without a corresponding increase in blood constituents other than guanidine known to give color with the reagent used. We believe this rise to be due to an accumulation of guanidine compounds in the blood.

A description of our exact procedure which is practically that of Major and Weber (35) follows: 10 cc. of oxalated blood are precipitated in a $100 \mathrm{cc}$. volumetric flask by the Folin-Wu (37) method for protein precipitation with the single difference that $2 / 3 \mathrm{~N}$ hydrochloric acid is used in place of $2 / 3 \mathrm{~N}$ sulphuric acid. Fifty cubic centimeters of the protein free filtrate are evaporated slowly to dryness on a hot plate or steam bath. The dry residue is then extracted repeatedly with small amounts of hot absolute atcohol with careful loosening of the residue with a rubber policeman to insure complete extraction of guanidine. The successive alcoholic extracts are filtered through a small filter and the total of 30 to $40 \mathrm{cc}$. of filtrate collected in a small beaker and evaporated just to dryness on a hot plate. Care should be exercised not to char the residue. The residue in the beaker is then dissolved in $5 \mathrm{cc}$. of distilled water and to this solution $1 \mathrm{cc}$. of the freshly prepared guanidine reagent described above is added. If the resulting colored solution is not perfectly clear it is shaken with a little powdered barium carbonate and filtered through a small high grade filter paper. The clear filtrate is allowed to stand 15 minutes and compared in a colorimeter with an appropriate standard solution of guanidine hydrochloride treated with the same reagent. Fifty cubic centimeters of protein free filtrate representing $5 \mathrm{cc}$. of normal blood usually require a standard containing $0.02 \mathrm{mgm}$. of guanidine (calculated as guanidine) in $6 \mathrm{cc}$. Abnormal bloods may require standards as high as $0.2 \mathrm{mgm}$. in the same volume. 
These very dilute solutions of guanidine do not keep well and our. method is to make fresh dilute solutions daily from a stock solution

TABLE 2

Recoveries of guanidine by colorimetric method under various conditions

\begin{tabular}{|c|c|c|c|c|}
\hline Substance and conditions of analysis & $\begin{array}{c}\text { Guani- } \\
\text { dine } \\
\text { found in } \\
\text { portion } \\
\text { analyzed }\end{array}$ & $\begin{array}{c}\text { Guani- } \\
\text { dine } \\
\text { present in } \\
\text { portion } \\
\text { analyzed }\end{array}$ & $\begin{array}{c}\text { Guani- } \\
\text { dine } \\
\text { found } \\
\text { per } 100 \\
\text { cc. blood }\end{array}$ & $\begin{array}{l}\text { Guani- } \\
\text { dine } \\
\text { present in } \\
100 \text { cc. } \\
\text { blood }\end{array}$ \\
\hline & mgm. & mgm. & mgm. & mgm. \\
\hline $\begin{array}{l}0.05 \text { mgm. guanidine in pure solution carried through } \\
\text { evaporation and extraction processes.......... }\end{array}$ & & & & \\
\hline $\begin{array}{l}0.10 \text { mgm. guanidine in pure solution carried through } \\
\text { evaporation and extraction processes............ }\end{array}$ & 0.097 & 0.100 & & \\
\hline${ }^{*} 50$ cc. of protein free blood filtrate......... & 0.026 & & 0.52 & \\
\hline 50 cc. of protein free blood filtrate......... & 0.025 & & 0.50 & \\
\hline $50 \mathrm{cc}$. of protein free blood filtrate..... & 0.026 & & 0.52 & \\
\hline $50 \mathrm{cc}$. of blood filtrate $+0.04 \mathrm{mgm}$. guanidine. & 0.063 & 0.065 & 1.26 & 1.30 \\
\hline 50 cc. of blood filtrate +0.04 mgm. guanidine. . & 0.060 & 0.065 & 1.20 & 1.30 \\
\hline $50 \mathrm{cc}$. of blood filtrate $+0.05 \mathrm{mgm}$. guanidine....... & 0.075 & 0.075 & 1.50 & 1.50 \\
\hline $\begin{array}{l}50 \mathrm{cc} \text {. of blood filtrate }+0.20 \text { mgm. guanidine } \ldots \ldots \ldots \\
10 \mathrm{cc} \text {. blood }+0.08 \mathrm{mgm} \text {. guanidine }-50 \mathrm{cc} \text {. filtrate }\end{array}$ & 0.204 & 0.225 & 4.08 & 4.50 \\
\hline 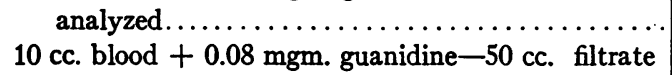 & 0.058 & 0.065 & 1.16 & 1.30 \\
\hline 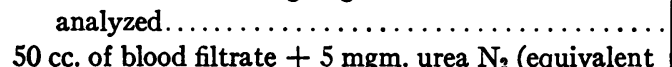 & 0.063 & 0.065 & 1.26 & 1.30 \\
\hline $\begin{array}{l}\text { to } 100 \text { mgm. urea } \mathrm{N}_{2} \text { per } 100 \text { cc. blood) .......... } \\
50 \text { cc. of blood filtrate }+2 \text { mgm. urea } \mathrm{N}_{2} \text { (equivalent }\end{array}$ & 0.042 & 0.025 & 0.84 & 0.50 \\
\hline $\begin{array}{l}\text { to } 40 \mathrm{mgm} \text {. urea } \mathrm{N}_{2} \text { per } 100 \mathrm{cc} \text {. blood) } \ldots \ldots \ldots \ldots \\
50 \text { cc. of blood filtrate }+5 \mathrm{mgm} \text {. creatinine (equiva- }\end{array}$ & 0.030 & 0.025 & 0.60 & 0.50 \\
\hline lent to $100 \mathrm{mgm}$. creatinine per $100 \mathrm{cc}$. blood)... . & 0.050 & 0.025 & 1.00 & 0.50 \\
\hline $\begin{array}{l}50 \mathrm{cc} \text {. of blood filtrate }+1.0 \mathrm{mgm} \text {. creatinine (equiva- } \\
\text { lent to } 20 \mathrm{mgm} \text {. creatinine per } 100 \mathrm{cc} \text {. blood).... }\end{array}$ & 0.032 & 0.026 & 0.64 & 0.50 \\
\hline $\begin{array}{l}10 \mathrm{cc} \text { of blood }+5 \mathrm{mgm} \text {. uric acid }+0.2 \mathrm{mgm} \text {. guani- } \\
\text { dine }-50 \mathrm{cc} \text {. of filtrate analyzed............... } \\
10 \mathrm{cc} \text { of blood }+5 \mathrm{mgm} \text {. uric acid }+0.2 \mathrm{mgm} \text {. guani- }\end{array}$ & 0.131 & 0.125 & 2.62 & 2.50 \\
\hline $\begin{array}{l}\text { dine }-50 \mathrm{cc} \text {. of filtrate analyzed............... } \\
50 \mathrm{cc} \text { of blood filtrate }+0.5 \mathrm{mgm} . \text { creatine (equiva- }\end{array}$ & 0.127 & 0.125 & 2.54 & 2.50 \\
\hline lent to $10 \mathrm{mgm}$. creatine per $100 \mathrm{cc}$. blood)........ & 0.060 & 0.025 & 1.20 & 0.50 \\
\hline $\begin{array}{l}50 \mathrm{cc} \text { of blood filtrate }+0.2 \mathrm{mgm} \text {. creatine (equiva- } \\
\text { lent to } 4.0 \mathrm{mgm} \text {. creatine per } 100 \mathrm{cc} \text {. blood)..... }\end{array}$ & 0.032 & 0.025 & 0.64 & 0.50 \\
\hline
\end{tabular}

*The same sample of blood was used in all following determinations.

of guanidine hydrochloride containing $1 \mathrm{mgm}$. of guanidine per cubic centimeter. The stock solution kept in the ice-box and pre- 
. served with toluene remains unchanged for at least a month but we have usually prepared a fresh supply at shorter intervals. When a series of unknowns are being analyzed it is well to prepare a series of standards because, as in all colorimetric work, it is not advisable to read against a standard color very different from that of the unknown solution.

The results in table 2 show the accuracy of this procedure in determining guanidine in pure solutions, normal blood, and in blood to which increased amounts of interfering substances have been added.

From these figures it appears that only in extreme nitrogen retention could the apparent increase in guanidine be attributed to the interference of the usual blood constituents. In repeated tests made by us and in an earlier rather extensive study by Lamson (1) no such retention was found in carbon tetrachloride poisoning.

Determination of guanidine and sugar levels in blood of dogs during carbon tetrachloride and chloroform poisoning and after guanidine administration

The method just described was applied to the study of blood samples taken before and at intervals after the administration of carbon tetrachloride to dogs under various conditions which are known to affect the toxicity of the drug. These figures, together with blood sugar and icteric index determinations on the same samples, are arranged in groups in table 3 and are discussed separately under appropriate headings.

\section{Carbon tetrachloride poisoning with high and low calcium meat diets.}

There is a tendency for the guanidine content of the blood to increase slightly several hours after the dose of carbon tetrachloride. This tendency is much exaggerated if meat is eaten. Because of the importance of meat in this respect animals even when on a low calcium diet sometimes escape serious symptoms if they persistently refuse to eat after receiving carbon tetrachloride. From the table it is seen that a rise in guanidine is followed within a few hours by a fall in blood sugar. The difference in the high and low calcium groups on meat diet (A and B) seems to lie in the severity of the subsequent 
TABLE 3

Determination of guanidine, blood sugar and icteric indices

\begin{tabular}{|c|c|c|c|c|c|}
\hline Dog number & Hours after dose & $\begin{array}{c}\text { Guani- } \\
\text { dine }\end{array}$ & $\begin{array}{l}\text { Blood } \\
\text { sugar }\end{array}$ & $\begin{array}{l}\text { Icteric } \\
\text { index }\end{array}$ & Remarks \\
\hline \multicolumn{6}{|c|}{ Group A-Dogs on meat-Low calcium diet $-4 \mathrm{cc}$. $\mathrm{CCl}_{4}$ per kilogram } \\
\hline & & mgm. & msm. & & \\
\hline 28-2-18 & Preliminary & 0.34 & 75 & 0 & \\
\hline \multirow[t]{6}{*}{ Weight $10.8 \mathrm{kgm}$. } & 5 hours & 0.33 & 91 & & Ate meat 6 hours after dose \\
\hline & 10 hours & 0.59 & 85 & & $\begin{array}{l}\text { Fine fibrillary twitching - } \\
\text { very sluggish }\end{array}$ \\
\hline & 23 hours & 0.33 & 93 & 2.5 & \\
\hline & $29 \frac{1}{2}$ hours & 0.36 & 73 & & $\begin{array}{l}\text { Ate meat } 30 \text { hours after } \\
\text { dose }\end{array}$ \\
\hline & 35 hours & 0.72 & 71 & & Quite sick. \\
\hline & 47 hours & 0.86 & 21 & 3.7 & $\begin{array}{l}\text { Very sick; conscious; can- } \\
\text { not stand; some tetany. } \\
\text { Violent spasm and death } \\
1 \text { hour later }\end{array}$ \\
\hline $28-6-2$ & Preliminary & 0.40 & 95 & 0 & \\
\hline \multirow[t]{5}{*}{ Weight $6.1 \mathrm{kgm}$. } & 23 hours & 0.52 & 73 & 1.5 & $\begin{array}{l}\text { Ate meat } 23 \frac{1}{2} \text { hours after } \\
\text { dose }\end{array}$ \\
\hline & 29 hours & 1.71 & 69 & & Sluggish \\
\hline & 47 hours & 0.68 & 64 & 3.5 & $\begin{array}{l}\text { Ate meat } 47 \frac{1}{2} \text { hours after } \\
\text { dose }\end{array}$ \\
\hline & 53 hours & 1.00 & 79 & & Good condition \\
\hline & 72 hours & 0.44 & 89 & 2.0 & Recovered \\
\hline \multirow{4}{*}{$\begin{array}{l}28-6-3 \\
\text { Weight } 4.5 \mathrm{kgm} .\end{array}$} & Preliminary & 0.37 & 78 & 0 & \\
\hline & 23 hours & 0.60 & 76 & 6.3 & $\begin{array}{l}\text { Ate a little meat after } \\
\text { sample }\end{array}$ \\
\hline & 29 hours & 1.55 & 70 & & Rather sluggish \\
\hline & 34 hours & 1.65 & 25 & 12.1 & $\begin{array}{l}\text { Just dead-died in con- } \\
\text { vulsion }\end{array}$ \\
\hline \multirow{6}{*}{$\begin{array}{l}28-6-4 \\
\text { Weight } 6.9 \mathrm{kgm} .\end{array}$} & Preliminary & 0.38 & 73 & 0 & \\
\hline & 23 hours & 0.48 & 62 & 1.0 & Refused to eat \\
\hline & 29 hours & 0.85 & 65 & & Fair condition \\
\hline & 47 hours & 0.92 & 66 & 2.0 & Refused to eat \\
\hline & 53 hours & 0.48 & 75 & & Rather quiet \\
\hline & 72 hours & 0.48 & 80 & Trace & Recovered \\
\hline \multirow{4}{*}{$\begin{array}{l}28-6-5 \\
\text { Weight } 5.6 \mathrm{kgm} .\end{array}$} & Preliminary & 0.38 & 83 & 0 & \\
\hline & 23 hours & 0.51 & 91 & Trace & Ate a little meat \\
\hline & 29 hours & 0.80 & 95 & & Quite sick \\
\hline & 54 hours & 0.96 & 24 & 2.5 & $\begin{array}{l}\text { Just dead } \\
\text { Considerable hemorrhage } \\
\text { in gastro-intestinal tract }\end{array}$ \\
\hline
\end{tabular}




\begin{tabular}{|c|c|c|c|c|c|}
\hline Dog number & Hours after dose & $\begin{array}{c}\text { Guani- } \\
\text { dine }\end{array}$ & $\begin{array}{l}\text { Blood } \\
\text { sugar }\end{array}$ & $\begin{array}{l}\text { Icteric } \\
\text { index }\end{array}$ & Remarks \\
\hline \multicolumn{6}{|c|}{ Group B-Dogs on meat-High calcium diet-4 cc. $\mathrm{CCl}_{4}$ per kilogram } \\
\hline & & $m g m$. & $m g m$. & & \\
\hline $28-6-7$ & Preliminary & 0.48 & 100 & 0 & \\
\hline \multirow[t]{5}{*}{ Weight $7.1 \mathrm{kgm}$. } & 21 hours & 0.48 & 93 & & $\begin{array}{l}\text { Ate meat }+ \text { calcium } 22 \\
\text { hours after dose }\end{array}$ \\
\hline & 27 hours & 0.51 & 80 & 1.0 & Good condition \\
\hline & 45 hours & 0.45 & 92 & 1.0 & $\begin{array}{l}\text { Ate meat }+ \text { Ca. salts } 46 \\
\text { hours after dose }\end{array}$ \\
\hline & 51 hours & 1.33 & 83 & & Good condition \\
\hline & 72 hours & 0.49 & 95 & & Good condition-recovered \\
\hline $28-6-8$ & Preliminary & 0.37 & 88 & 0 & \\
\hline \multirow[t]{5}{*}{ Weight 8.4 kgm. } & 21 hours & 0.44 & 88 & & Very quiet-refused to eat \\
\hline & 27 hours & 0.66 & 87 & 9.8 & \\
\hline & 45 hours & 0.55 & 78 & 10.0 & Refused to eat \\
\hline & 72 hours & 0.89 & 84 & 8.6 & Ate a little meat + calcium \\
\hline & 96 hours & 0.40 & 90 & 2.0 & Recovered \\
\hline $28-6-9$ & Preliminary & 0.40 & 95 & 0 & \\
\hline \multirow[t]{5}{*}{ Weight $8.1 \mathrm{kgm}$. } & 21 hours & 0.40 & 80 & & \\
\hline & 27 hours & 0.96 & 95 & 3.1 & $\begin{array}{l}\text { Ate meat }+ \text { calcium at } 22 \\
\text { hours }\end{array}$ \\
\hline & 45 hours & 0.50 & 87 & 2.5 & $\begin{array}{l}\text { Ate meat }+ \text { calcium at } 46 \\
\text { hours }\end{array}$ \\
\hline & 51 hours & 0.88 & 78 & & \\
\hline & 72 hours & 0.46 & 84 & Trace & Well-discharged \\
\hline $28-6-10$ & Preliminary & 0.34 & 93 & 0 & \\
\hline \multirow{6}{*}{ Weight $7.0 \mathrm{kgm}$. } & 21 hours & 0.44 & 78 & & Ate meat at 22 hours \\
\hline & 27 hours & 0.96 & 64 & 3.5 & \\
\hline & 45 hours & 1.63 & 69 & 2.5 & Refused to eat \\
\hline & 72 hours & 1.71 & 66 & 10.8 & Very sick \\
\hline & 96 hours & 0.80 & 70 & 5.0 & Much better \\
\hline & 120 hours & 0.40 & 80 & 2.0 & Recovered \\
\hline & Preliminary & 0.47 & 75 & & \\
\hline \multirow[t]{6}{*}{ Weight $9.9 \mathrm{kgm}$. } & 6 hours & 0.50 & 100 & & Refused to eat \\
\hline & 24 hours & 0.66 & 43 & & Very quiet and sick \\
\hline & 48 hours & 0.61 & 42 & 10.0 & $\begin{array}{l}\text { Ate meat }+ \text { calcium salts- } \\
\text { very quiet }\end{array}$ \\
\hline & 72 hours & 0.61 & 68 & 12.5 & \\
\hline & 102 hours & 0.30 & 56 & & Did not eat \\
\hline & 132 hours & 0.33 & 83 & & Recovered \\
\hline
\end{tabular}


TABLE 3-Continued

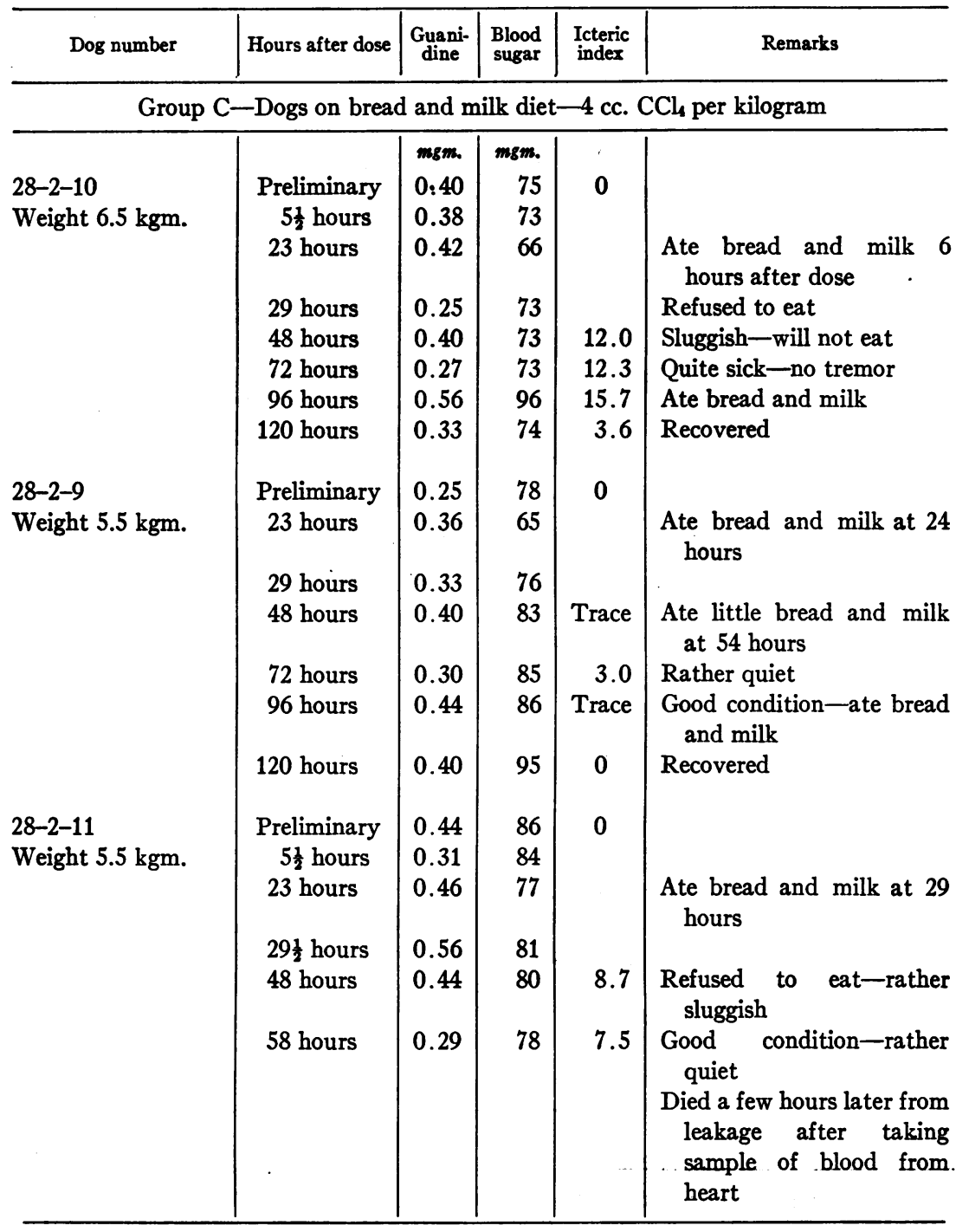


TABLE 3-Continued

\begin{tabular}{|c|c|c|c|c|c|}
\hline Dog number & Hours after dose & $\begin{array}{c}\text { Guani- } \\
\text { dine }\end{array}$ & $\begin{array}{l}\text { Blood } \\
\text { sugar }\end{array}$ & $\begin{array}{c}\text { Icteric } \\
\text { index }\end{array}$ & Remarks \\
\hline \multicolumn{6}{|c|}{ Group D-Dogs receiving $4 \mathrm{cc}$. $\mathrm{CCl}_{4}+4 \mathrm{cc}$. alcohol per kilogram } \\
\hline & & mgm. & $m g m$. & & \\
\hline $28-4-8$ & Preliminary & $0.34^{*}$ & 73 & 0 & \\
\hline \multirow{2}{*}{$\begin{array}{l}\text { Low calcium meat } \\
\text { diet } \\
\text { Weight } 4.4 \mathrm{kgm} .\end{array}$} & & 1.06 & 65 & 11.7 & Ate little meat-vomited it \\
\hline & & 0.75 & 20 & & \\
\hline \multirow{3}{*}{$\begin{array}{l}28-4-9 \\
\text { Low calcium meat } \\
\text { diet } \\
\text { Weight } 4.3 \mathrm{kgm} \text {. }\end{array}$} & Preliminary & 0.37 & 78 & & \multirow{3}{*}{$\begin{array}{l}\text { Tetanic convulsions } \\
\text { Tetanic convulsions and } \\
\text { death }\end{array}$} \\
\hline & lours & 0.42 & 51 & & \\
\hline & 33 & 0.66 & 20 & & \\
\hline 28-4-11 & Preliminary & 0.46 & 78 & 0 & \multirow{3}{*}{$\begin{array}{l}\text { Ate meat at } 21 \text { hours. } \\
\text { Tremors noted } \\
\text { In coma-died few minutes } \\
\text { later }\end{array}$} \\
\hline \multirow{2}{*}{$\begin{array}{l}\text { Low calcium meat } \\
\text { diet } \\
\text { Weight } 5.6 \mathrm{kgm} \text {. }\end{array}$} & 20 hours & 1.23 & 78 & & \\
\hline & 43 hours & 1.61 & 50 & 15.9 & \\
\hline \multirow{2}{*}{$\begin{array}{l}28-4-12 \\
\text { Low calcium meat } \\
\text { diet }\end{array}$} & Prel & $0.48+$ & 71 & 0 & \multirow{3}{*}{$\begin{array}{l}\text { Ate meat at } 21 \text { hours } \\
\text { Quite sick-quiet } \\
\text { Very sick-barely con- } \\
\text { scious-died 2-3 hours- } \\
\text { later }\end{array}$} \\
\hline & $\begin{array}{l}20 \text { hours } \\
26 \text { hours }\end{array}$ & $\begin{array}{l}0.80 \\
1.60\end{array}$ & $\begin{array}{l}62 \\
54\end{array}$ & 4.9 & \\
\hline Weight $4.8 \mathrm{kgm}$. & 34 hours & 0.83 & 48 & & \\
\hline \multirow{5}{*}{$\begin{array}{l}28-2-20 \\
\text { Mixed diet. High } \\
\text { calcium. } \\
\text { Weight } 10.9 \mathrm{kgm} .\end{array}$} & Preliminary & 0.48 & 86 & 0 & \multirow{5}{*}{$\begin{array}{l}\text { Ate meat at } 5 \text { hours } \\
\text { Muscle twitching } \\
\text { Very sick-lying on side- } \\
\text { muscle twitching. } \\
\text { Violent tetanic convul- } \\
\text { sions-died shortly after } \\
\text { last sample }\end{array}$} \\
\hline & $\begin{array}{l}4 \text { hours } \\
7 \text { hours }\end{array}$ & $\begin{array}{l}0.46 \\
0.76\end{array}$ & $\begin{array}{l}79 \\
68\end{array}$ & & \\
\hline & 11 hours & 1.20 & 43 & & \\
\hline & 24 hours & 1.26 & 25 & & \\
\hline & 30 hours & 0.87 & 23 & 9.3 & \\
\hline
\end{tabular}

* The corresponding creatine concentrations for this and the following blood samples of this animal are $3.11,2.39$, and $2.43 \mathrm{mgm}$. per $100 \mathrm{cc}$. of blood respectively.

$\dagger$ The corresponding creatine concentrations for this and the following blood samples of this animal are $3.00,1.25,1.20$ and $1.00 \mathrm{mgm}$. per $100 \mathrm{cc}$. of blood respectively. 
TABLE 3-Continued

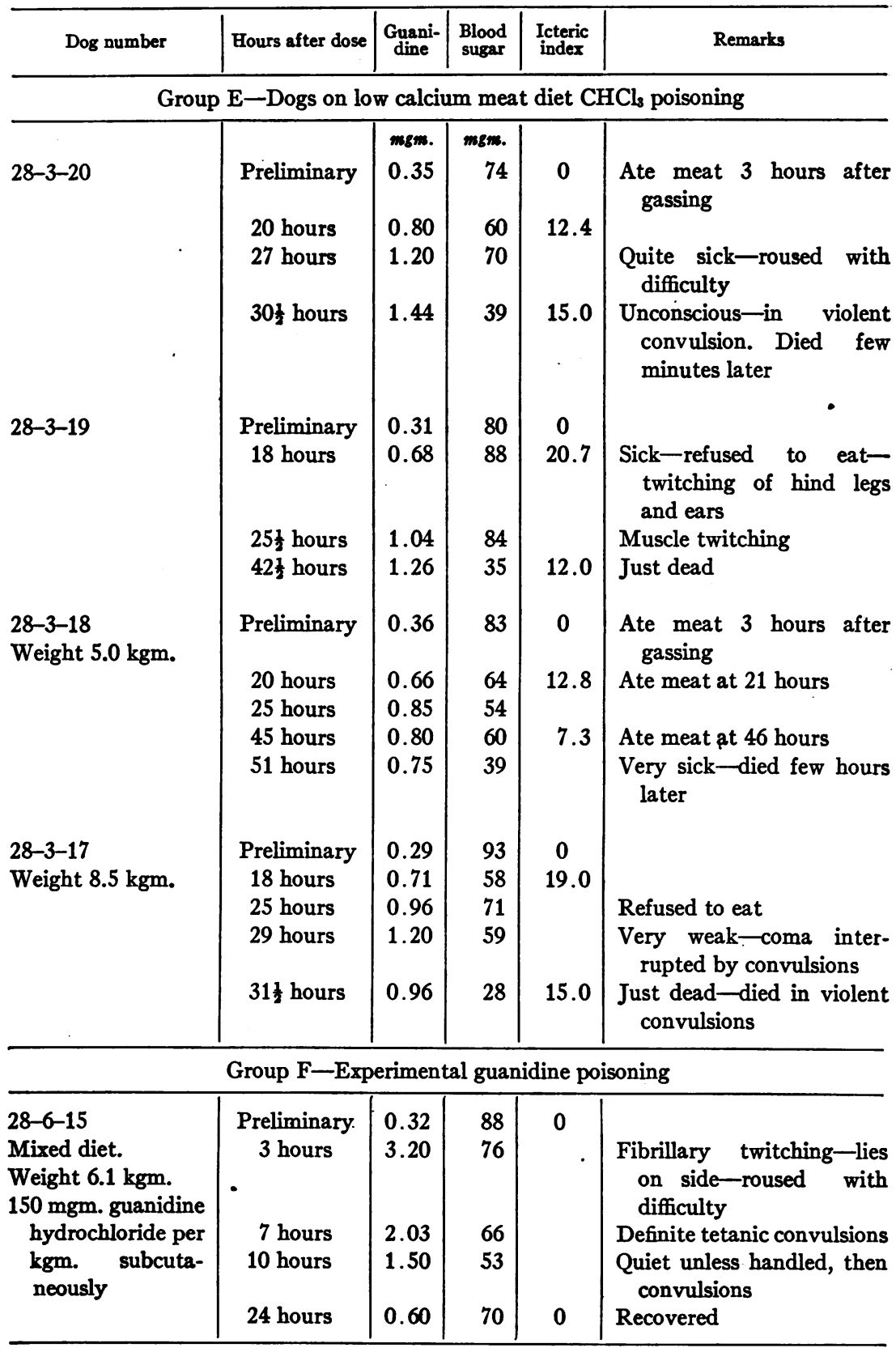




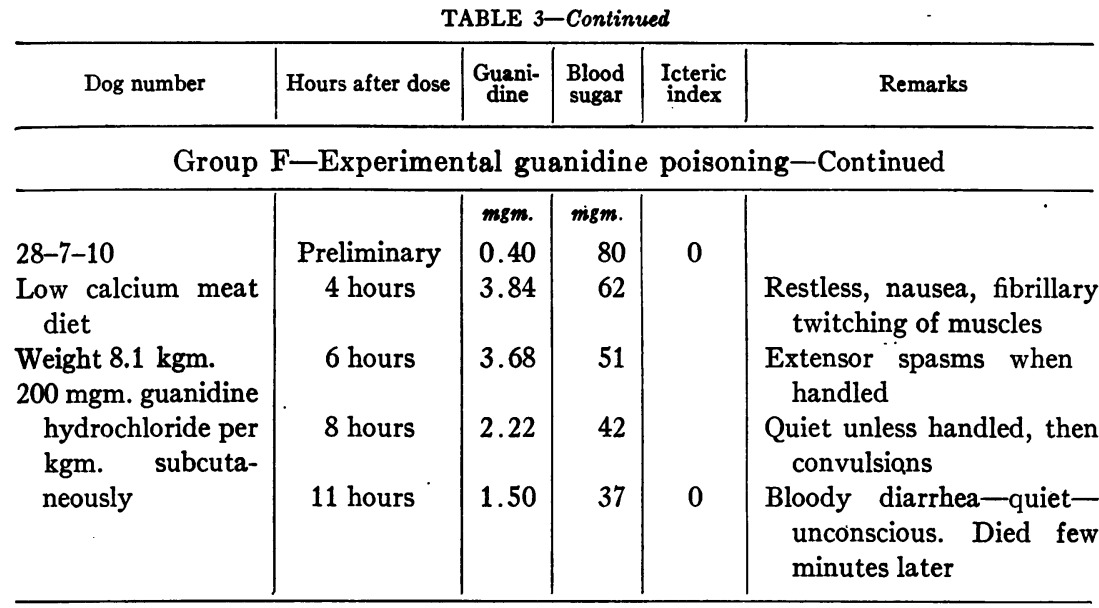

hypoglycemia rather than in the concentrations of guanidine reached. Further evidence that calcium is responsible for the avoidance of dangerously low blood sugar levels in the animals in Group B is furnished by later experiments (see chart A) in which rapidly falling blood sugar concentrations are maintained above the danger level by the administration of calcium salts. One of the few exceptions to the usual rule of low resistance to intoxication in low calcium animals is represented in the second member of Group A. In spite of low calcium intake and the production of a high guanidine concentration in the blood a safe blood sugar level is maintained. The low icteric index too is like those seen in animals on high calcium diet. In the other direction an occasional animal on high calcium diet will succumb with the same symptoms and blood changes shown by animals on deficient calcium diet. We have been unable to avoid a few such discrepancies in each group. However, when a condition is being studied in which nitrogen, sugar, and calcium metabolisms seem all to be involved this is perhaps not to be wondered at. Feeding calcium cannot guarantee its absorption and utilization, nor can dogs with varying previous life histories all be brought to comparable degrees of calcium lack by 2 or 3 weeks of special diet.

Carbon tetrachloride poisoning with bread and milk diet. To avoid the rise in guanidine produced by eating meat 10 animals were run on bread and milk diet and all gave consistent results. Three typical 
ones make up Group $\mathrm{C}$ in table 3. The bread and milk diet was fed for several days preliminary to the dose of carbon tetrachloride and whenever the dogs ate after the dose. There is no significant rise in guanidine after eating and no fall in blood sugar. These animals all recovered without serious symptoms despite high icteric indices in some cases-a finding which further argues against the suggestion that bilirubinemia alone produces the symptoms of acute calcium lack.

Carbon tetrachloride and alcohol poisoning. The increased toxicity of carbon tetrachloride if given with alcohol (1) manifests itself here as shown in Group D by much higher and more rapid rises in guanidine with subsequent extreme hypoglycemia soon followed by death. The increases in guanidine usually occur even if meat is not eaten after the dose, the guanidine in such cases evidently being of endogenous origin. Alcohol given alone causes no such accumulation of guanidine even when large amounts of meat are eaten. Dogs on a high calcium meat diet usually fail to survive a dose of $4 \mathrm{cc}$. of carbon tetrachloride per kilogram with alcohol unless given intensive calcium medication. If death is not caused by hemorrhages, which tend to be more severe than when carbon tetrachloride is given alone, this intoxication can be controlled by calcium therapy in the same way as the cases described in the earlier protocols in this paper.

Chloroform poisoning. In order to compare the effects produced by chloroform a well known liver poison and one closely related chemically to carbon tetrachloride, a few cases of chloroform poisoning are included in Group E. The dogs were exposed in a gassing chamber for $1 \frac{1}{2}$ hours to a concentration of chloroform just sufficient to maintain complete anesthesia. The recovery from the anesthesia was prompt and complete but 12 to 24 hours later the typical intoxication characterized by increased guanidine and low blood sugar concentrations in the blood is seen. The severity of the intoxication is comparable to that seen when carbon tetrachloride is given with alcohol.

Experimental guanidine poisoning. Before any causal relationship can be claimed between the symptoms noted in any of these cases and the concentrations of guanidine in the blood which we have demonstrated it is necessary to show that the doses of guanidine hydro- 
chloride which produce similar symptoms do so by producing comparable concentrations of guanidine in the blood. To demonstrate this 12 cases of guanidine poisoning have been studied and the concentrations of guanidine in the blood determined. All cases gave similar results and three are included in Table 3 as Group F. Our figures are in close agreement with those reported by Major, Orr and Weber (38). Although the values range somewhat higher than those usually reached in carbon tetrachloride poisoning they are still of the same general order of magnitude. It must also be remembered that in carbon tetrachloride and chloroform poisoning the depression of ionized calcium due to the retention of bile pigments would tend to increase the effect of a given concentration of guanidine above that produced in a normal animal.

\section{The effect of calcium on the hypoglycemias seen in carbon tetrachloride intoxication and guanidine poisoning}

Looking back to the protocols describing the prompt relief following the administration of calcium salts to dogs with severe carbon tetrachloride intoxication, it seems probable that a large factor in the cures must have been a restoration to normal of the very low blood sugar levels. Underhill and Blatherwick (39) (40) have shown that the hypoglycemia after parathyroidectomy can be relieved by calcium administration. Watanabe (24) was, however, unable to influence the low blood sugar levels produced by guanidine administration by the subcutaneous administration of calcium lactate. We believe that this failure was due to inadequate calcium therapy. The subcutaneous administration of calcium lactate is a very slow way of furnishing calcium ions to cases of such acute need as is seen in guanidine poisoning. We have found that calcium chloride administered intravenously will usually restore the blood sugar to normal in either carbon tetrachloride or guanidine poisoning. Even the administration of calcium chloride by mouth often suffices to check a rapidly falling blood sugar in animals in carbon tetrachloride poisoning. Such a restoration is not accomplished by reducing the guanidine concentration because a return to normal blood sugar can be brought about during a period when the guanidine concentration in the blood is steadily rising. This point as well as the prompt elevation of blood 
sugar is well illustrated by chart A. Very similar results were obtained in 8 other cases. It is not as easy to get these clean-cut results in experimental guanidine poisoning, not, we believe, because of any real difference in the intoxication but because when a subcutaneous injection of guanidine hydrochloride is being gradually absorbed it is

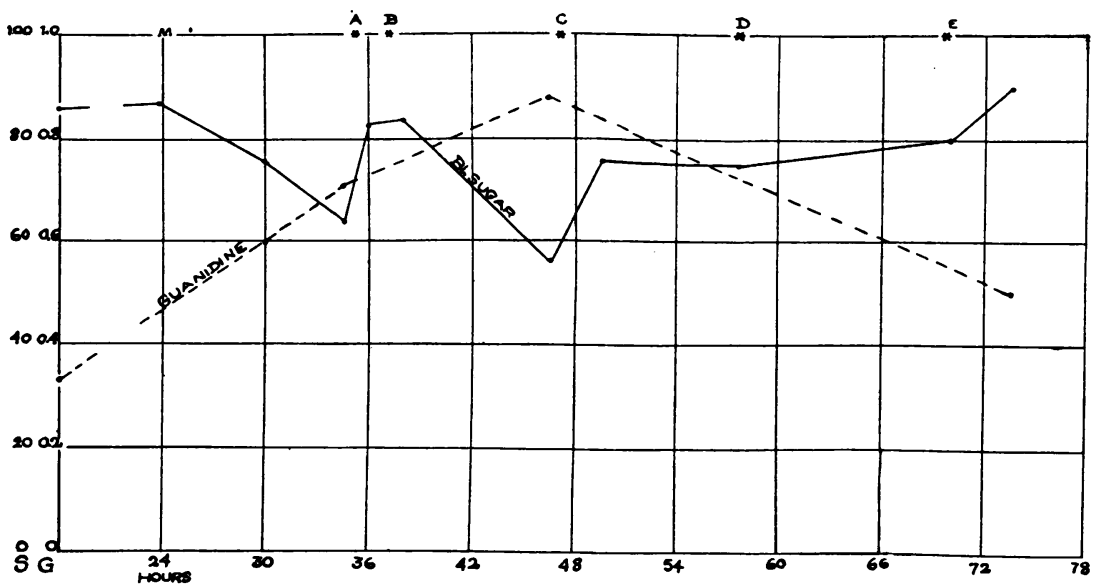

Chart A. Showing Effect of Calcium Administration on Blood Sugar Concentration in Carbon Tetrachloride Poisoning

The figures for blood sugar $(S)$ and guanidine $(G)$ are in terms of milligrams per $100 \mathrm{cc}$. of blood.

Dog no. 28-5-16. On low calcium meat diet for 12 days before receiving $4 \mathrm{cc}$. of $\mathrm{CCl}_{4}$ per kilogram. Typical symptoms of intoxication developed after a meal of meat was eaten 24 hours after dose.

$M$, meat was eaten; ${ }^{*} A, 50$ cc. 5 per cent calcium chloride given by stomach tube; ${ }^{*} B, 75 \mathrm{cc} .5$ per cent calcium chloride given by stomach tube; ${ }^{*} C$, dog vomited a dose of $\mathrm{CaCl}_{2}$ given by stomach tube and was given $400 \mathrm{mgm} . \mathrm{CaCl}_{2}$ intravenously as 5 per cent solution; ${ }^{*} D, 150 \mathrm{mgm}$. $\mathrm{CaCl}_{2}$ given intravenously as 5 per cent solution, ${ }^{*} E, 50 \mathrm{cc} .5$ per cent calcium chloride given in $50 \mathrm{cc}$. milk by stomach tube.

Each elevation of blood sugar to normal was accompanied by great improvement in the dog's general condition and the animal finally recovered.

more difficult to gauge properly the amount of calcium required. Satisfactory restoration of blood sugar has, however, been obtained in several experiments. Chart B illustrates a case in which the blood sugar was raised to a safe level by calcium administration and fell again to extreme hypoglycemia when medication was withheld. 
Sometimes after prolonged and very severe intoxication produced either by guanidine or carbon tetrachloride, death occurs in spite of intravenous administration of calcium chloride. We hope in later work to show that these failures occur when there has been a depletion

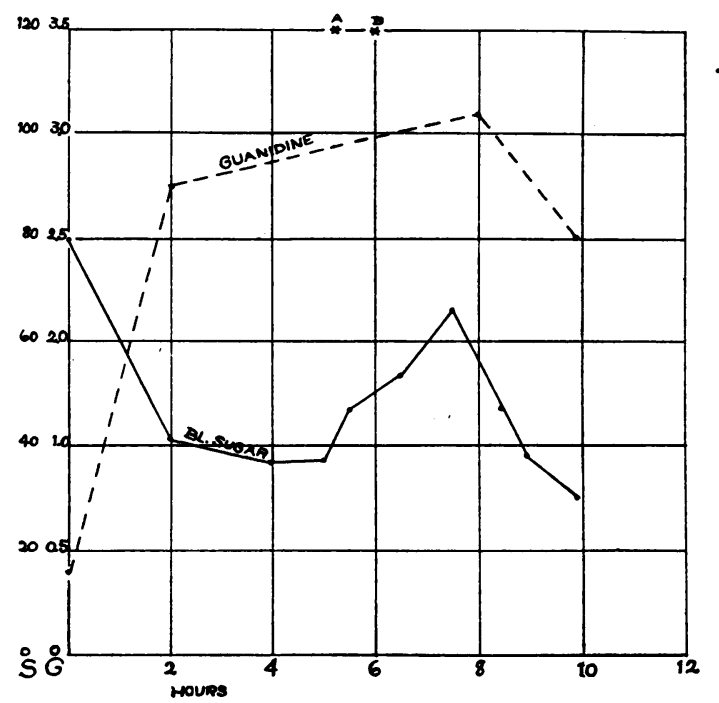

Chart B. Effect of Calcium Administration on Blood Sugar Concentration in Expermmental Guanidine Poisoning

The figures for blood sugar $(S)$ and guanidine $(G)$ are in terms of milligrams per 100 cc. of blood.

Dog. no. 28-6-19. On low calcium meat diet for 2 to 3 weeks before receiving $200 \mathrm{mgm}$. guanidine hydrochloride per kilogram subcutaneously. Typical severe intoxication developed after the administration of the dose.

$* A, 500 \mathrm{mgm}$. $\mathrm{CaCl}_{2}$ given intravenously as 10 per cent solution; ${ }^{*} B, 300 \mathrm{mgm}$. $\mathrm{CaCl}_{2}$ given intravenously as 10 per cent solution.

The symptoms were much relieved during the time that the blood sugar was elevated. After medication was withheld the dog grew rapidly worse, convulsions reappeared, and death occurred 10 hours after the dose with a blood sugar concentration of $30 \mathrm{mgm}$. per $100 \mathrm{cc}$. blood.

of all the glycogen from the liver. Under these conditions calcium chloride can hardly be expected to furnish the needed sugar. The method by which in the successful cases blood sugar is increased after calcium is furnished is at present unknown. The return of blood 
sugar to normal in either type of intoxication is accompanied by a marked improvement in the condition of the animal. These results indicate that in saving the life of the animal perhaps the most essential antagonistic effect of calcium to an increased amount of guanidine is the restoration of the blood sugar level. This is not the only antagonism between the two substances, however, because when the sugar level is maintained by sugar administration the symptoms of hyperexcitability and convulsions are undiminished or even increased until calcium is also given. Thus the first empirical calcium treatment succeeded because both the hypoglycemia and hyperexcitability due to increased guanidine retention were relieved.

\section{DISCUSSIỌN}

Obviously many questions have been raised by the observations reported above that can only be answered after further experimental work. Very little definite information seems to be available regarding the source and normal disposal of guanidine and such information will have to precede any final explanation of the abnormal retention seen in carbon tetrachloride and chloroform poisoning. From the similar effect produced by both these drugs which are known to be liver poisons one is tempted to associate the accumulation of guanidine with the failure on the part of the liver to contribute some step in normal metabolism. It must be borne in mind, however, that although the most conspicuous injury has been done to the liver some other organ may also have been damaged and may be the one chiefly concerned in guanidine metabolism. The literature suggests that the parathyroids must not be forgotten in this connection. Paton and Findlay (41) believe that the detoxifying action of the parathyroid gland is responsible for the prevention of abnormal concentrations of guanidine in the blood under normal conditions, and that the removal or injury of these glands may lead to dangerous increases of this constituent. Frank, Stern, and Nothmann (28) after their careful study likewise conclude that the parathyroids are concerned with the maintenance of a proper concentration of guanidine compounds in the blood though they do not agree with all the claims made by the Paton School. Many other authorities doubt any such activity on the part of the parathyroids (42) (43). It is hoped that pathological and 
functional studies already under way will be able to answer the question as to whether these glands have been damaged by the drugs which we know bring about a retention of guanidine. Whatever the normal disposal of guanidine is, it seems to be a very effective one because relatively enormous doses of guanidine must be administered to a normal dog to produce a concentration of 2 to $3 \mathrm{mgm}$. of guanidine per $100 \mathrm{cc}$. of blood. At present we can only state that both carbon tetrachloride and chloroform cause a serious interference with this mechanism and a retention of guanidine results. The toxic symptoms produced by this retained guanidine are very similar to those seen in experimental guanidine poisoning. The outstanding features of both intoxications are gastro-intestinal irritation, nervous hyperexcitability followed by depression, extreme hypoglycemia, and death. In both conditions calcium has a highly favorable action. In carbon tetrachloride poisoning the need for calcium is rendered doubly acute by the increased guanidine and the simultaneous depletion of calcium ions by a retention of bile pigments. When this need is met by furnishing calcium most cases of intoxication can be prevented or cured.

Practical suggestions regarding the management of a case to be treated with carbon tetrachloride would emphasize first of all the importance of a liberal amount of calcium in the preliminary diet. In order to avoid the tendency toward increased guanidine in the blood meat should be avoided and a diet rich in calcium and carbohydrate substituted. A bread and milk diet is an easy method of furnishing both calcium and carbohydrate in adequate amounts. With these precautions cases of intoxication should be extremely rare. If poisoning should occur, a combination of calcium chloride and dextrose therapy seems indicated and in our experience has nearly always proved effective.

\section{SUMMARY AND CONCLUSIONS}

1. Carbon tetrachloride produces a severe intoxication in dogs on a meat diet which is low in calcium while the addittion of calcium salts to the meat diet, or the feeding of a liberal mixed diet without meat causes a high degree of tolerance to the drug. Furthermore, cases of poisoning can usually be cured by calcium therapy.

2. The outstanding features of the intoxication are gastro-intestinal 
irritation, nervous hyperexcitability usually followed by depression, bilirubinemia, a retention of guanidine in the blood and hypoglycemia. Pathological studies show a severe central necrosis of the liver.

3. A similar but more severe toxic picture is presented in chloroform poisoning or when alcohol is given with carbon tetrachloride.

4. A causal relationship between the retained guanidine in these intoxications and the symptoms noted is indicated by the fact that the maintenance of similar concentrations of guanidine in the blood of a normal dog by the administration of guanidine hydrochloride produces an intoxication in which there is close similarity to carbon tetrachloride poisoning both in the quality and severity of symptoms produced. Calcium also has a highly beneficial action in guanidine poisoning.

5. The basis for the relief and protection afforded by calcium in carbon tetrachloride poisoning seems to lie in its antagonistic effect to the retained guanidine. The following points support this hypothesis:

$a$. Despite similar degrees of liver injury and comparable retentions of guanidine, dogs on a high calcium diet show no acute intoxication, while in dogs on a low calcium diet the increase in guanidine is soon followed by nervous symptoms, gastro-intestinal irritation, hypoglycemia and death.

$b$. When calcium is administered to poisoned animals the nervous symptoms are relieved and the blood sugar levels restored to normal. This relief is based on at least two antagonistic actions between calcium and guanidine because if the blood sugar is raised by dextrose administration the hyperexcitability persists until calcium is also given.

c. Calcium has been shown to have essentially the same effects in experimental guanidine poisoning.

6. At least three factors contribute to the acute need for calcium in carbon tetrachloride poisoning, $(a)$ the deficient calcium intake, $(b)$ the need for extra calcium to combat the effects of guanidine, and (c) the reduction of ionized calcium in the blood by combination with retained bile pigments.

7. Practical suggestions for the safe use of carbon tetrachloride would emphasize the importance of a liberal calcium diet and the avoidance of meat which tends to increase guanidine retention. 
This investigation is one of a series of studies being made under the direction of Dr. P. D. Lamson on the pharmacology and toxicology of carbon tetrachloride. The work is being carried on with the support of the International Health Board.

\section{BIBLIOGRAPHY}

1. Lamson, P. D., Gardner, G. H., Gustafson, R. K., Maire, E. D., McLean, A. J., and Wells, H. S., J. Pharmacol. and Exper. Therap., 1923, xxii, 215. The Pharmacology and Toxicology of Carbon Tetrachloride.

2. Minot, A. S., Proc. Soc. Exper. Biol. and Med., 1927, xxiv, 617. The Relation of Calcium to the Toxicity of Carbon Tetrachloride in Dogs.

3. Meyer, J. R., and Pessoa, S. B., Am. J. Trop. Med., 1923, iii, 177. A Study on the Toxicity of Carbon Tetrachloride.

4. Davis, N. C., J. Med. Res., 1923-4, xliv, 601. The Influence of Diet upon Liver Injury by Carbon Tetrachloride.

5. Collip, J. B., J. Am. Med. Assoc., 1927, lxxxviii, 565. The Calcium Mobilizing Hormone of the Parathyroid Glands-Chemistry and Physiology.

6. Rosenthal, S. M., Johns Hopkins Hosp. Bull., 1922, xxxiii, 432. A New Method of Testing Liver Function with Phenoltetrachlorphthalein.

7. van den Bergh, A-A. Hymans, and Snapper, J., Deut. Arch. f. klin. Med., 1913, cx, 540. Die Farbstoffe des Blutserums.

8. Bernheim, A. R., J. Am. Med. Assoc., 1924, lxxxii, 291. The Icteric Index. (A Quantitative Estimation of Bilirubinemia.)

9. Clark, E. P., and Collip, J. B., J. Biol. Chem., 1925, lxiii, 461. A Study of the Tisdall Method for the Determination of Blood Serum Calcium with a Suggested Modification.

10. King, J. H., and Stewart, H. A., J. Exper. Med., 1909, xi, 673. The Effect of the Injection of Bile on the Circulation.

11. King. J. H., Bigelow, J. E., and Pearce, L., J. Exper. Med., 1911, xiv, 159. Experimental Obstructive Jaundice.

12. Bowler, J. P., and Walters, W., Ann. Surg., 1924, lxxx, 545. The Toxicity and Rate of Excretion of Calcium Chlorid from the Blood Stream.

13. Buchbinder, W. C., and Kern, R., Arch. Int. Med., 1927, xl, 900. Experimental Obstructive Jaundice. I. Growth Factor in Defective Calcification.

14. Benedict, S. R., J. Biol. Chem., 1926, lxviii, 759. The Estimation of Sugar in Blood and Normal Urine.

15. Folin, O., and Wu, H., J. Biol. Chem., 1920, xli, 367. A System of Blood Analysis. Supplement I. A Simple and Improved Method for the Determination of Sugar.

16. Gergens, E., and Baumann, E., Arch. f. d. ges. Physiol., 1876, xii, 205. Ueber das Verhalten des Guanidin, Dicyandiamidin, und Cyanamid in Organismus.

17. Putzeys, F., and Swaen, A., Arch. f. d. ges. Physiol., 1876, xii, 597. Ueber die physiologische Wirkung des schwefelsauren Guanidins. 
18. Fühner, H., Arch. f. exper. Path. u. Pharmakol., 1908, lviii, 1, Curarestudien. I. Die periphere Wirkung des Guanidins.

19. Fühner, H., Arch. f. exper. Path. u. Pharmakol., 1925, cv, 265. Utber die Guanidinkontraktur des Skelettmuskels.

20. Camis, M., J. Physiol., 1909, xxxix, 73. Physiological and Histological Observations on Muscles Chiefly in Relation to the Action of Guanidine.

21. Watanabe, C. K., J. Biol. Chem., 1918, xxxiii, 253. Studies in the Metabolic Changes Induced by Administration of Guanidine Bases. I. Influence of Injected Guanidine Hydrochloride Upon Blood Sugar Content.

22. Watanabe, C. K., J. Biol. Chem., 1918, xxxiv, 51. II. The Influence of Guanidine upon Urinary Ammonia and Acid Excretion.

23. Watanabe, C. K., J. Biol. Chem., 1918, xxxiv, 65. III. The Relation Between the Tetanoid Symptoms of Guanidine Administration and the Condition of Acidosis.

24. Watanabe, C. K., J. Biol. Chem., 1918, xxxiv, 73. IV. The Influence of the Administration of Calcium upon Blood Sugar Content in Rabbits with Guanidine Hypoglycemia.

25. Watanabe, C. K., J. Biol. Chem., 1918, xxxvi, 531. V. The Change of Phosphate and Calcium Content in Serum in Guanidine Tetany and the Relation between the Calcium Content and Sugar in the Blood.

26. György, P., and Vollmer, H., Arch. f. exper. Path. u. Pharmacol., 1922, xcv, 200. Beeinflussung der Guanidinvergiftung durch Säurezufuhr.

27. Paton, D. N., and Findlay, L., Quart. J. Exper. Physiol., 1916, x, 318. The Parathyroids: Tetania Parathyreopriva. Its Nature, Cause, and Relation to Idiopathic Tetany. Part IV. The Etiology of the Condition and its Relation to Guanidin and Methyl Guanidin Intoxication.

28. Frank E., Stern, R., and Nothmann, M., Ztschr. f. d. ges. exper. Med., 1921, xxiv, 341. Die Guanidin-und Dimethylguanidin-Toxikose des Säugetiers und ihre physio-pathologische Bedeutung.

29. Chandler, A. C., and Chopra, R. N., Indian J. Med. Res., 1926, xiv, 219. Effects of the Administration of Sugar, Magnesium Sulphate, Sodium Citrate, and Dilute Acid on the Liver Damage Done by Carbon Tetrachloride.

30. Nelken, L., Ztschr. f. d. ges. exper. Med., 1923, xxxii, 348. Über den Einfluss der Guanidinvergiftung auf den Ca-und Phosphatgehalt des Blutes.

31. Bayer, G. Ztschr. f. d. ges. exper. Med., 1922, xxvii, 119. Über den Calciumgehalt des. Blutes bei der Guanidinvergiftung. Ein Beitrag sur Tetaniefrage.

32. Tiegs, O. W., Australian J. Exper. Biol. and Med. Sci., 1924, i, 93. A Color Test for Guanidine Bases Together with Some Physiological Applications.

33. Marston, H. R., Australian J. Exper. Biol. and Med. Sci., 1924, i, 99. Colorimetric Method for the Estimation of Guanidine and Methylguanidine.

34. Pfiffner, J. J., and Meyer, V. C., Proc. Soc. Exper. Biol. and Med., 1925-6, 
xxiii, 830. The Colorimetric Estimation of Methyl Guanidine in Biological Fluids. (Preliminary Report.)

35. Major, R. H., and Weber, C. J., Johns Hopkins Hosp. Bull., 1927, xl, 87. The Probable Presence of Increased Amounts of Guanidine in the Blood of Patients with Arterial Hypertension.

36. Major, R. H., and Weber, C. J., Arch. Int. Med., 1927, xl, 891. The Possible Increase of Guanidine in the Blood of Certain Persons with Hypertension.

37. Folin, O., and Wu, H., J. Biol. Chem., 1919, xxxviii, 81. A System of Blood Analysis.

38. Major, R. H., Orr, T. G., and Weber, C. J., Johns Hopkins Hosp. Bull., 1927, xl, 287. Observations on the Blood Guanidine in Tetania Parathyreopriva.

39. Underhill, F. P. and Blatherwick, N. R., J. Biol. Chem., 1914, xviii, 87. Studies in Carbohydrate Metabolism. VI. The Influence of Thyreoparathyroidectomy upon the Sugar Content of the Blood and the Glycogen Content of the Liver.

40. Underhill, F. P., and Blatherwick, N. R., J. Biol. Chem., 1914, xix, 119. Studies in Carbohydrate Metabolism. VII. The Influence of Subcutaneous Injections of Dextrose and of Calcium Lactate upon the Blood Sugar Content and upon Tetany after Thyreoparathyroidectomy.

41. Paton, D. N., and Findlay, L., Quart. J. Exper. Physiol., 1916, x, 377. The Parathyroids: Tetania Parathyreopriva: Its Nature, Cause and Relation to Idiopathic Tetany. VIII. The Function of the Parathyroids and the Relationship of Tetania Parathyreopriva to Idiopathic Tetany.

42. Greenwald, I., J. Biol. Chem., 1924, lxi, 33. Is There a Toxin in the Blood of Parathyroidectomized Dogs?

43. Dragstedt, L. R., Physiol. Rev., 1927, vii, 499. The Physiology of the Parathyroid Glands. 